\title{
Medicinal plants cultivated in urban home gardens in Heredia, Costa Rica
}

\author{
Roxana González-Ball ${ }^{1 *} \mathbb{B}$, Tania Bermúdez-Rojas ${ }^{1}$, Marilyn Romero-Vargas ${ }^{1}$ and Melissa Ceuterick ${ }^{2}$
}

\begin{abstract}
Background: Urban ethnobotanical research in Costa Rica is rather rare and home gardens are poorly studied so far. Investigating their biodiversity is crucial in gathering knowledge on the uses of this particular flora, especially related to the owners' health. This study therefore explores the diversity and knowledge of medicinal plants of private garden owners from three different urban neighborhoods in Heredia, Costa Rica, an thus far understudied area.

Methods: Semi-structured interviews $(n=61)$ were conducted with garden owners in three socioeconomically different urban neighborhoods (Central Heredia, Maria Auxiliadora and Bernardo Benavides). Information was collected about medicinal plants cultivated in the garden, treatments, plant part used and mode of administration. All species were identified and their geographical origin was determined. This information was then compared with the available regional and local (ethno)pharmacopoeias to detect possible newly documented uses.
\end{abstract}

Results: The majority or $90 \%$ of garden owners who also held knowledge on medicinal plants species were women $(n=30)$ of all ages (between 26 and 85 years old). A list of 27 species of medicinal plants was obtained from the participants of three urban neighborhoods. In Central Heredia, $74 \%(n=20)$ of the total species were present, in Maria Auxiliadora 33\% ( $n=9)$ and in Bernardo Benavides 56\% ( $n=15)$. Most plant species were used by the participants to treat respiratory problems (11 spp.), hair and skin problems (9 spp.) and digestive disorders (8 spp.). Some plants were used to treat multiple ailments (10 spp.). About a third of all species $(n=8)$ were used by the participants to treat disorders that were not indicated in the regional and local pharmacopoeias. More specifically, Aloe saponaria, Blechum pyramidatum, Costus scaber, Impatiens walleriana, Lippia alba, Tradescantia zebrina, Psidium friedrichsthalianum and Solenostemon scutellarioides used for medicinal purposes by the participants were not found in the above-mentioned resources.

Conclusions: The present study provides new information about the use of medicinal plants in a thus far understudied urban area in Costa Rica. We documented new medicinal uses for several plants listed in the regional and local pharmacopoeias as well as for plants not previously reported in an urban environment. In general, there is little information about the types of plants used for medicinal purposes in urban ecosystems in Costa Rica. Although the country has a high endemic diversity of plants, many exotic medicinal plant species were introduced by the Spaniards during the colonization and by Afro-Costa Rican descendants. The present results thus show how the diversity of the medicinal plants used by these garden owners' confirms a socioeconomic gradient and reflects both Costa Rica's colonial history as well as the current epidemiological profile of the country. These findings underline the need for more ethnobotanical research in urban areas in Costa Rica.

Keywords: Urban ethnobotany, Home gardens, Medicinal plants, Costa Rica

*Correspondence: 2blog013@gmail.com

${ }^{1}$ Universidad Nacional, Heredia, Costa Rica

Full list of author information is available at the end of the article original author(s) and the source, provide a link to the Creative Commons licence, and indicate if changes were made. The images or other third party material in this article are included in the article's Creative Commons licence, unless indicated otherwise in a credit line to the material. If material is not included in the article's Creative Commons licence and your intended use is not permitted by statutory regulation or exceeds the permitted use, you will need to obtain permission directly from the copyright holder. To view a copy of this licence, visit http://creativecommons.org/licenses/by/4.0/. The Creative Commons Public Domain Dedication waiver (http://creativeco mmons.org/publicdomain/zero/1.0/) applies to the data made available in this article, unless otherwise stated in a credit line to the data. 


\section{Background}

There is a growing attention in ethnobiological literature to what Nabhan has called the ethnobiosphere in urban environments [1]. Urban home or domestic gardens are important indicators of medicinal plant use in the city [2, 3 ] and are therefore important sites to understand urban health practices and biocultural knowledge transfers [4, 5]. Medicinal plants form an important component of global health care as they are utilized as a main source of treatment in many developing countries and increasingly also in the global north [6]. Latin-America forms no exception to this trend, medicinal plants are widely employed in home medicine and phytotherapy in rural areas, often by indigenous and mestizo communities [4, 7], and in general, medicinal treatments form the second most important use category of local floras across the continent [8].

Urban ethnobotanical studies in Latin-America have so far mainly focused on (i) market studies [9-14] documenting the diversity of medicinal plant species sold, (ii) the dynamics of ethnobotanical practices of transnational and internal migrant communities [15-22] and to a lesser extent on (iii) urban home gardens. Home gardens have been studied in several Latin-American countries such as Mexico, Guatemala, Ecuador, Argentina and Brazil [23-27]. Some of these studies have explored cultivation of medicinal plants in different locations ranging from urban over suburban to rural home gardens [7, 28, 29], while others have focused more on identifying types of medicinal plant knowledge shared between rural and urban locations [23, 30]. In general, studies that focus on the floristic composition of home-gardens and other private green spaces often tend to report a relatively low percentage of species used for medicinal purposes compared to species used as food or ornamentals. A study in Nicaragua, for example [29], resulted in 293-total plant species, primarily used as ornamentals, although some medicinal plants were mentioned as well. A plant survey conducted in Bogota, Colombia, showed that a meagre $9 \%$ of the total plants registered were used medicinally, but only sparse information was given by the garden owners [31]. In addition, in a study in the Brazilian city of São Luís (Maranhão State) medicinal plants only represented $7.5 \%$ of the total [32]. Palheta and colleagues [27], on the other hand, found 127 medicinal species in the city of Abaetetuba in Brazil used as medicine. These varied findings not only point to a potential socioeconomic gradient in medicinal plant diversity and knowledge as we will describe further, but also indicate that documenting intra- and intercultural knowledge of medical plant diversity is much needed and also necessary to achieve conservation goals [33]. As such urban home gardens can contribute to both ecological, economic and social sustainability [8], which is ever so urgent in light of global climate change [6].

As a middle-income country with an advanced welfare and social security system, Costa Rica stands out from its neighboring countries in Central-America, for its excellent health outcomes [34], its economic and political stability and general social progressiveness [35]. In addition, Costa Rica has a long history of conservation of its exceptional biodiversity [36]. Despite the rich medicinal flora of the country, consisting of over 500 medicinal plant species (belonging to 104 genera) - of which $37 \%$ are harvested from their natural habitats and 126 are commercialized species $[37,38]$ - very little ethnobotanical research has been carried out, and even less so on the use of medicinal plants in urban areas. Ethnobotanical studies in Costa Rica have mainly focused on (i) specific species, growth forms or habitats [39-43] or on (ii) ethnobotanical practices within different indigenous communities [44-47]. However, to date, hardly any research has been conducted on the cultivation of medicinal plants in private urban domestic gardens and the knowledge surrounding their uses, other than the study by Madaleno and colleagues [48]. In the latter study, the authors compiled an inventory of medicinal plants used in San José based on interviews with urban gardeners, medicinal plant vendors from several local markets and a professional herbalist. Other research has only indirectly touched upon the use of medicinal plants in urban settings. García et al. [49] conducted interviews with patients at the Hospital Clinic in the capital San José, which revealed no less than 51 different plant species used for medicinal purposes.

The present study aims to close this gap in the existing urban ethnobotanical literature on Costa Rica by documenting the range of medicinal plants used by owners of urban private gardens (home gardens) in three socioeconomically different neighborhoods in Heredia (Central Heredia, Maria Auxiliadora and Bernardo Benavides). This is a previously unstudied area and thus provides new insights in the field.

\section{Methods \\ Description of the study area}

The study was conducted in the city of Heredia, located in the Central Valley, which is part of the greater urban area of Costa Rica, called the Gran Área Metropolitana Region (GAM). Heredia county has a total population of 19,138 inhabitants [50] in an area of just three $\mathrm{km}^{2}$ and has a population density of 6379.33 inhabitants per $\mathrm{km}^{2}$ which makes this the third largest city in Costa Rica, after the capital San José and Alajuela. With respect to the ethnic background of the inhabitants, most identify as white or mestizo (of mixed European and Amerindian heritage) 
in the population census of 2011 [51]. Heredia is a popular destination for economic migration within the country, as well as from the neighboring country Nicaragua [52]. With respect to the climate, the average annual rainfall is $2374.3 \mathrm{~mm}$. The wettest months are September and October with average amounts of $410.88 \mathrm{~mm}$ and $424.6 \mathrm{~mm}$, respectively [53]. A more detailed ecological description of the area can be found in [54].

\section{Selection of field sites}

Findings on the possibility of a socioeconomic gradient in biodiversity and ethnobotanical plant knowledge tend to differ across the literature [55-57]. Some studies have shown that more affluent urban neighborhoods tend to have a higher species richness, yet also show that these species are more often non-native, purely ornamental species, while garden owners from less affluent areas often cultivate more utilitarian, native species $[55,56]$ to provide food and medicines. A recent meta-analysis by Kuras and colleagues [57] offered a more nuanced interpretation to this dichotomous view. To avoid bias and to reach maximum variation and address possible intracultural variation in field sites and possible ethnobotanical practices, three types of socioeconomically different neighborhoods in Heredia were selected for the recruitment of urban domestic garden owners (see Fig. 1). We selected a mixed area characterized by commercial activities and housing (i.e. Central Heredia, here further referred to as $\mathrm{UH}$ ), a residential area with a higher socioeconomic status (i.e. Maria Auxiliadora further referred to as MA) and a welfare housing development area (i.e. Bernardo Benavides further abbreviated as BB), as described in [58].

In the next step, gardens were identified through a stratified, random sample using Google Earth maps and the ArcGis software. The above information was later corroborated using a GPS to record the position of each garden. Subsequently, $10 \%$ of the total sample was selected for each category using SPSS. Each of the thus selected garden owners was contacted and invited to participate after providing information about the purpose of the research. If they did not agree to participate, another number from the generated random table was selected in order to complete the designated number of gardens devised for each of the three neighborhoods.

\section{Characteristics of the gardens}

We defined domestic or home gardens as green areas (including backyards) that are located on the perimeter of a private property and contain plants that are grown in soil (and not in plant pots). This research was conducted only in urban domestic gardens whose owners lived in a home on the property, but did not take into account allotments or green areas of apartments or condominiums [54].

Prior visits to garden owners were made to obtain oral consent for participation. An information letter from the School of Biology at the Universidad Nacional de Costa Rica was presented to explain the purpose of the encompassing research project on urban private gardens by the first author $[54,58]$. After giving oral consent and approval for the author to enter their property during their presence, garden owners were interviewed anonymously. The total sample consisted of 61 home gardens in the three types of neighborhoods [54, 58] with a total of 35 gardens in UH, 12 in MA and 14 in BB.

\section{Semi-structured interviews}

To explore and describe garden owners' knowledge and uses of medicinal plants in these Costa Rican urban gardens, a qualitative research design was followed after [59-61]. The semi-structured interview topic guide was validated during a pilot test which was conducted in a public park in the studied area with 50 garden owners who were asked to validate all questions [54]. The semistructured questions focused on the floristic composition as well as on uses and management of the urban private domestic gardens [54]. Part of the results on the floristic diversity of these gardens has been previously published [58]. For the purpose of the current study, data were selected on cultivated medicinal plants and sociodemographic characteristics of the garden owners. Garden owners were asked which plants in their garden they used for medicinal purposes. We thus probed for active uses rather than for latent or passive knowledge [62]. Additional information was asked about the common name(s), exact treatment, used plant parts and preferred mode of administration. A total of 61 garden owners were interviewed between October 2011 and December 2012. They were selected based on garden ownership to validate that the correct information of each plant was given. General data about the 61 gardens, such as garden area, as well as gender and age of the participants, have been described extensively in $[54,58]$. Of the 61 interviewed garden owners, 30 reported using and cultivating medicinal plants in their garden, corresponding to 12 for $\mathrm{BB}, 4$ for MA and 14 for HU. The majority or $90 \%(n=27)$ are female and only $10 \%(n=3)$ are male. Their ages ranged from 26 to 85 years old $(26-29 n=2$, $32 n=1,40-49 n=2$ and $50 \geq$ years old $n=25$ ).

\section{Identification of plant species}

All medicinal plant species were identified in situ by the first author, who is a trained biologist with emphasis in 


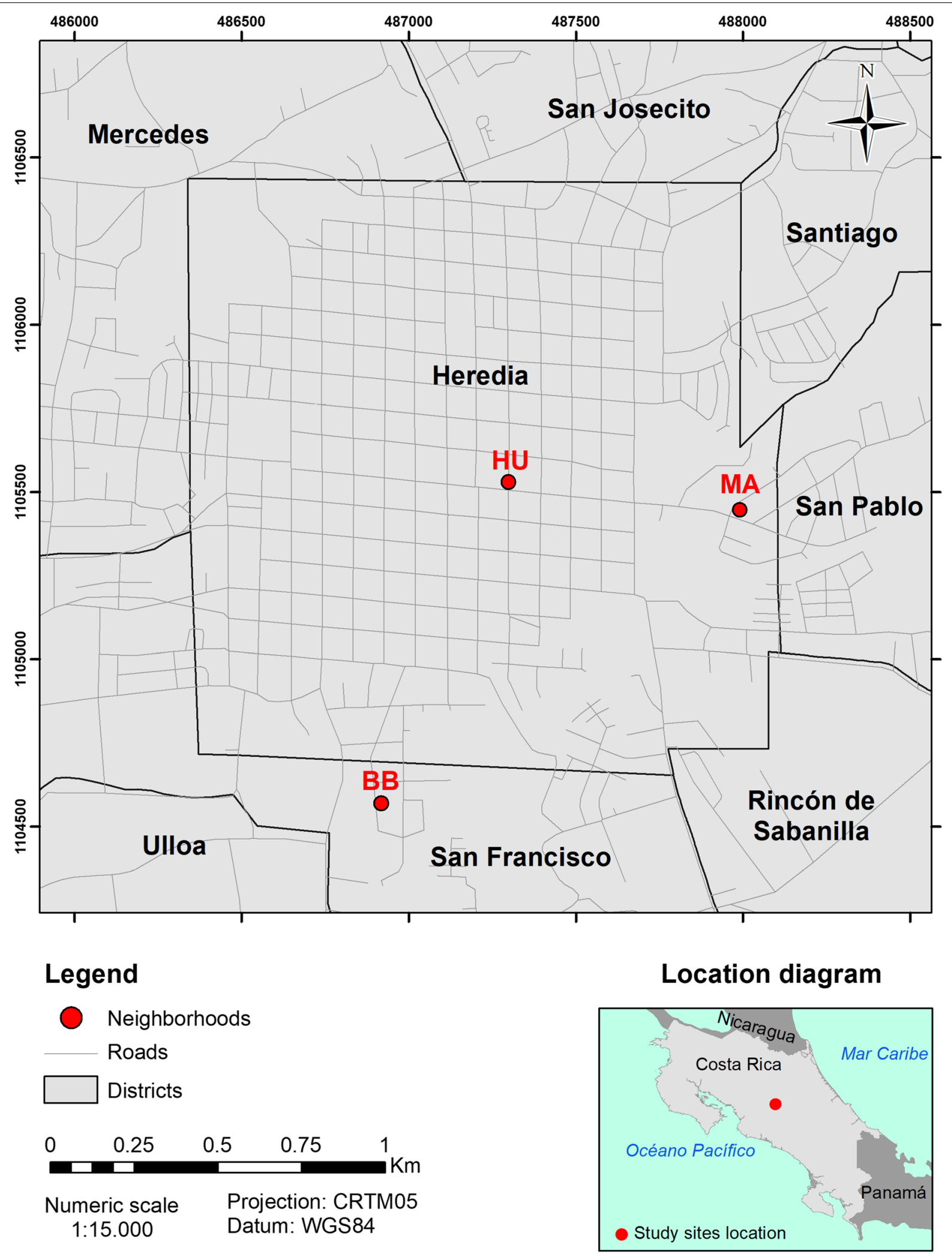

Fig. 1 Location of the three neighborhoods where the urban private gardens were visited in Heredia, Costa Rica 
botany. In addition, photographs were taken for the purpose of creating a digital voucher collection of the medicinal plants used in the studied gardens.

\section{Data analysis}

Data obtained from the interviews were entered in a Microsoft Excel file in order to carry out descriptive statistics. Furthermore, information of the documented treatment mode of each medicinal plant was compared to the regional pharmacopoeias [63-71] in addition to the local Costa Rican literature on medicinal plants [72-75]. The comparison between fieldwork data and literature entries was based on the scientific names of the species used (see also [76]). In addition, relevant literature was reviewed in order to identify the geographical distribution of the medicinal plant species found.

\section{Results}

\section{Plant species used}

A total of 27 plant species (Table 1) used for medicinal purposes were found in the urban home gardens among the three different neighborhoods in Heredia (with UH $n=20$ sp., MA $n=9$ sp., BB $n=15$ sp.). This is equivalent to $4 \%$ of the total floristic composition of 612 species of plants found in all studied gardens [54]. The main categories of uses include ornamentals (73\%), plants without any specific use (15\%) and fruits (6\%) [54]. Table 1 provides an overview of the medicinal species used by the interviewed garden owners, including their Spanish common names, illnesses treated and neighborhood, information from the local pharmacopoeia, plant parts used, mode of preparation, use frequency and the origin of the plant species.

The 27 medicinal plants belong to 17 plant families. Lamiaceae and Myrtaceae are the most common plant families with each four species, Asparagaceae with three species followed by Verbenaceae with two species. All other species belong to different families. On species level, Aloe vera, Aloe saponaria and Salvia rosmarinus were reported most often by the participants (37\%, 23\% and 23\%, respectively). Followed by Mentha piperita, Ruta chalepensis and Lippia graveolens (each used by $17 \%$ of the respondents). The rest of the medicinal plant species were used by less than $11 \%$ of the participants. Over a third of all medicinal species $(n=12)$ were found in at least two gardens. Aloe vera, Aloe saponaria and Salvia rosmarinus are among the more frequently cultivated medicinal species in the private gardens (Fig. 2). From the total number of medicinal species encountered, several of these species have been reported in San José before: Mentha piperita var. citrata and M. spicata, Salvia rosmarinus, Aloe vera, Ruta graveolens, Cymbopogon citratus, Lippia alba, L. graveolens, Justicia pectoralis, Salvia rosmarinus, Mentha piperita, Eucalytus spp., Zingiber officinale, Ruta chalepensis, Tanacetum parthenium and Tradescantia zebrina $[48,49]$.

In the area with the lowest socioeconomic status (BB), $86 \%$ of all garden owners reported at least one medicinal plant, in the mixed area (HU) $40 \%$ of all garden owners reported at least on medicinal species and in the residential area with a higher socioeconomic status (MA) only $33 \%$. These findings confirm a socioeconomic gradient in the diversity of medicinal species and knowledge.

\section{Origins of plant species}

As shown in Fig. 3, only 33\% of the species grown in these Heredian home gardens are native to Costa Rica (i.e., Blechum pyramidatum, Justicia tinctoria, Eryngium foetidum, Tradescantia zebrina, Costus scaber, Nopalea cochenillifera, Psidium friedrichsthalianum, Buddleja americana and Lippia alba), while $44 \%$ of all species are native to the Neotropics in general. The rest originated outside the continent, $37 \%$ of all medicinal species in this study have their origins in Europe and Africa, and 19\% in Asia and Australia.

\section{Plant part used and dosage}

As shown in Table 1, participants did not always indicate a specific dosage. Instead, they would often state that they use 'several leaves' or a 'bunch of the plant.' Leaves were the most commonly used plant part. This is unsurprising, as leaves are a tender part of the plant from which people can use simple extraction techniques [100], while fresh leaves produce larger quantities of active substances such as alkaloids, essences, glucosides and tannins [101] and are easy to use and available in major amounts throughout the year [27].

\section{Illnesses treated}

Figure 4 shows the different illnesses treated and the number of medicinal plant species used by the participants. These clusters include emic illness categories and are categorized and presented here as they were mentioned by the participants. Most plants found in the urban gardens are used to treat respiratory problems $(n=11)$, hair and skin problems $(n=9)$ and digestive disorders $(n=8)$. These are all considered common, minor ailments, which are usually treated first with home-remedies in the hierarchy of the resort. 


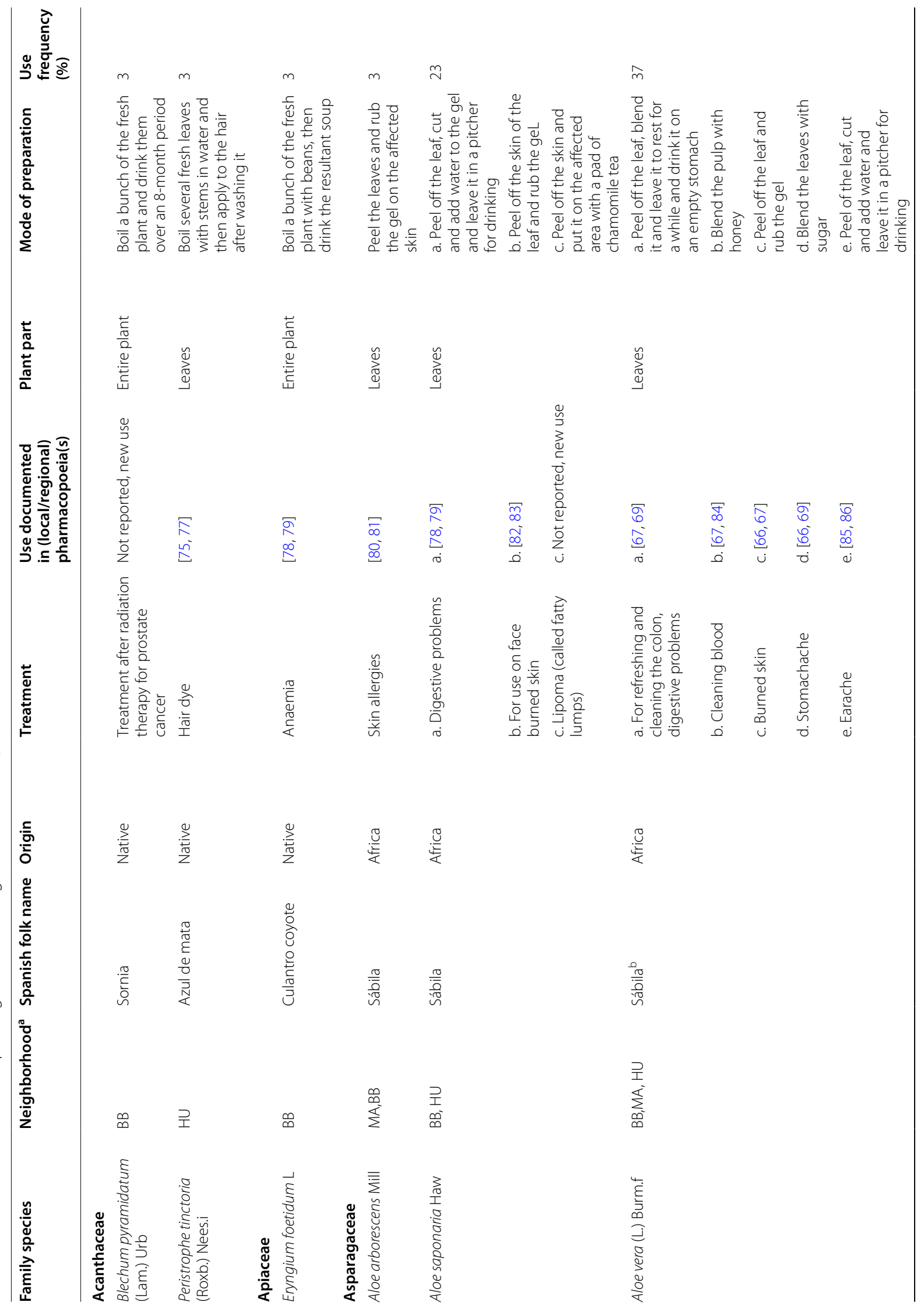




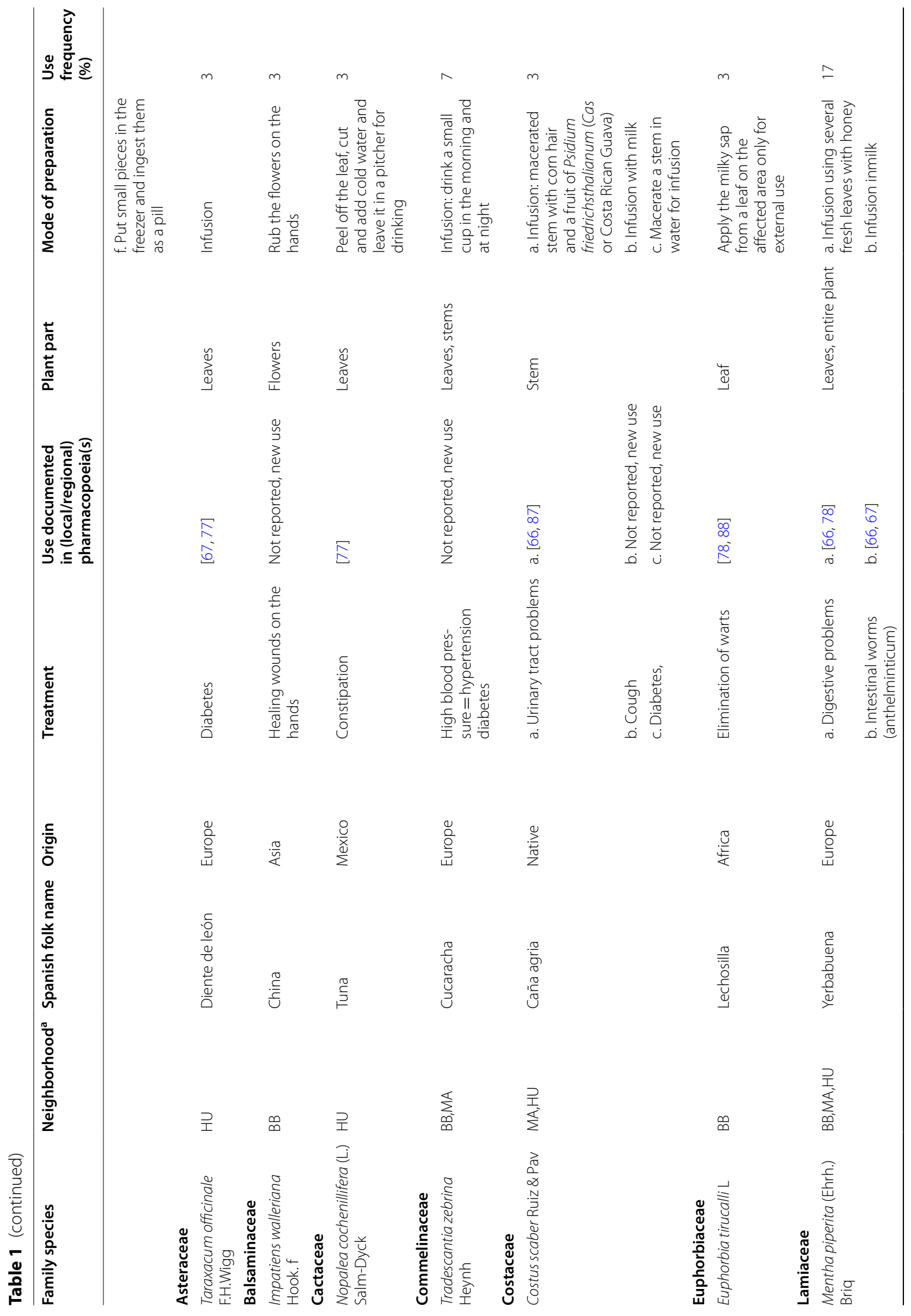




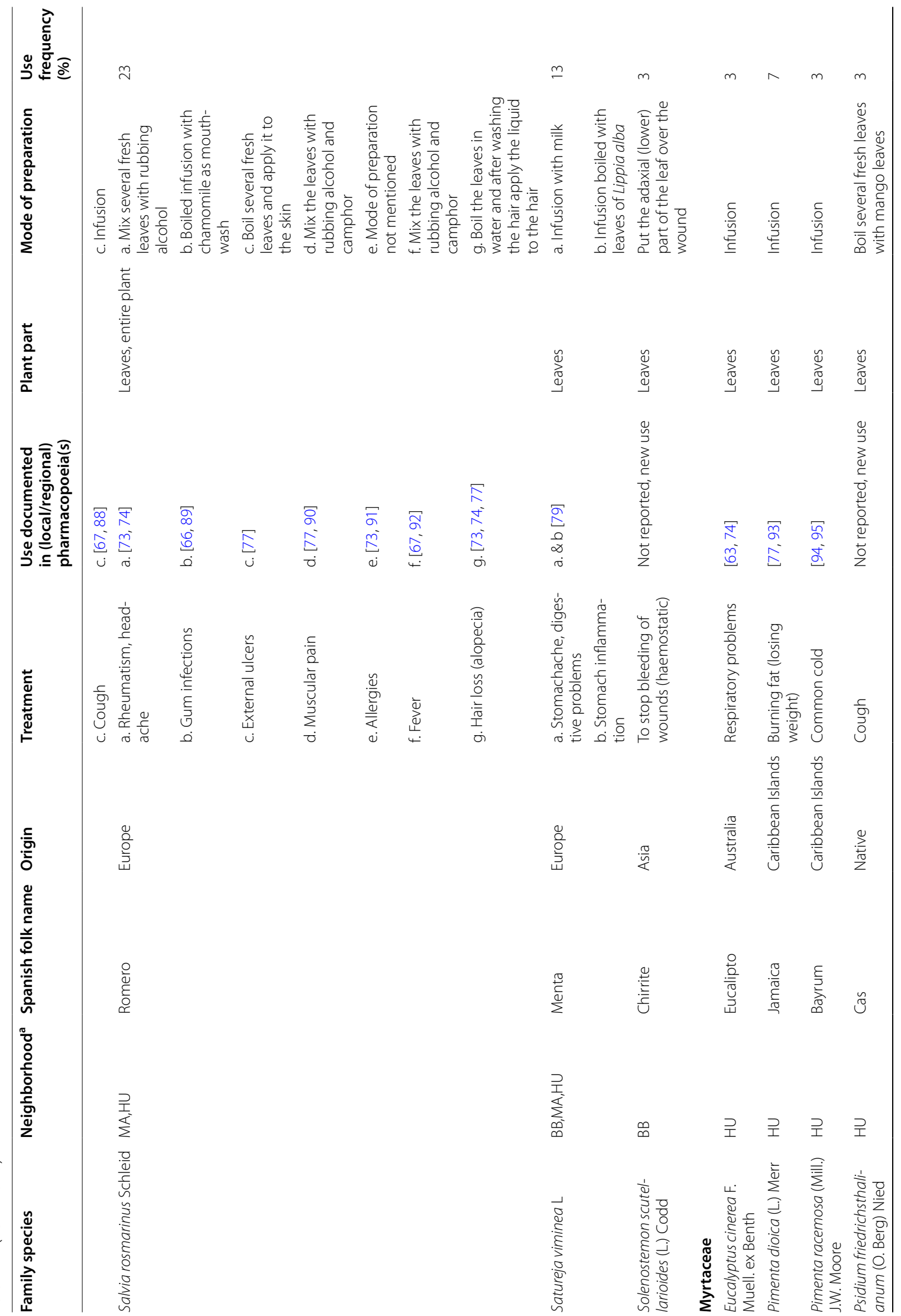




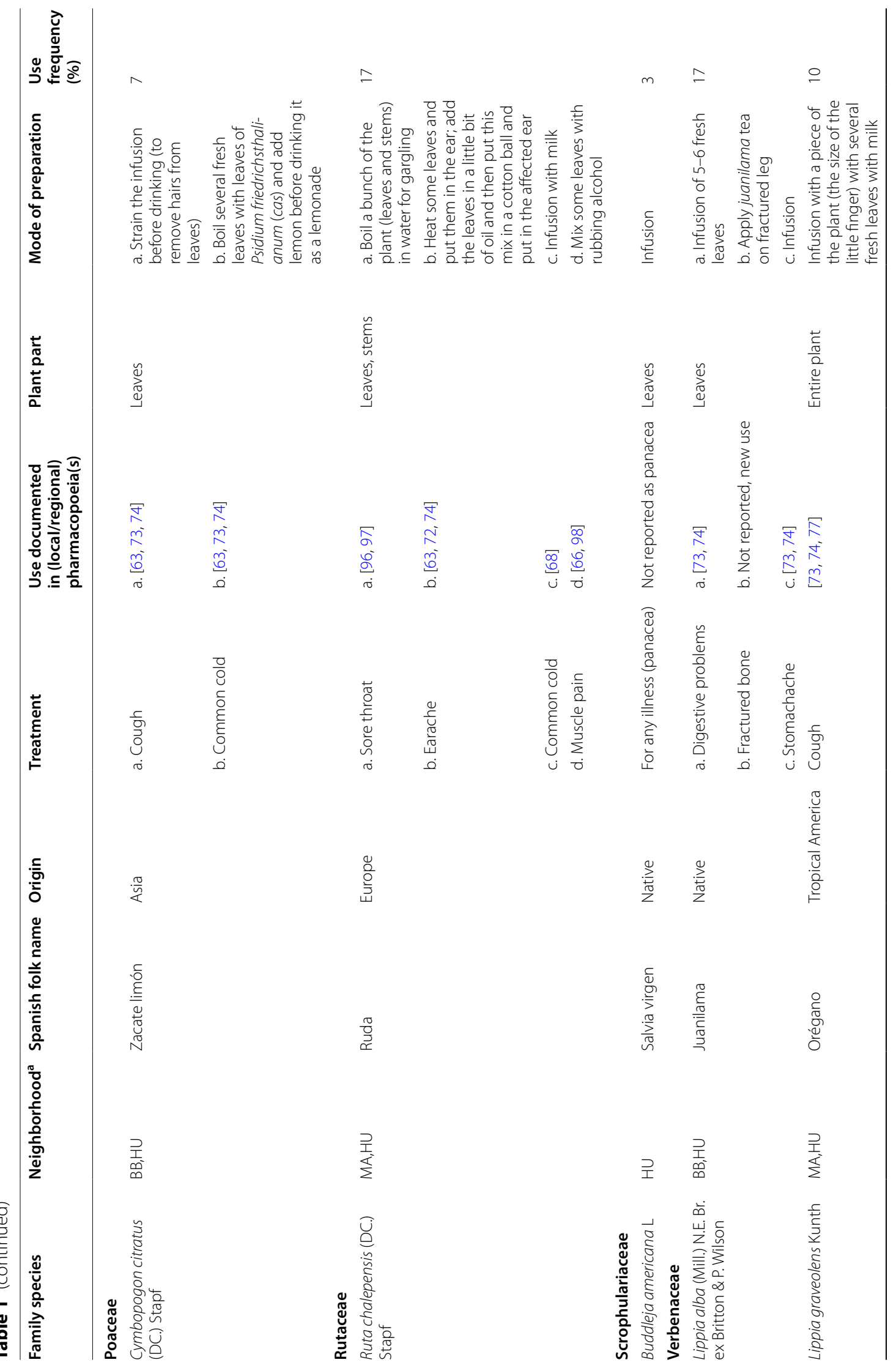




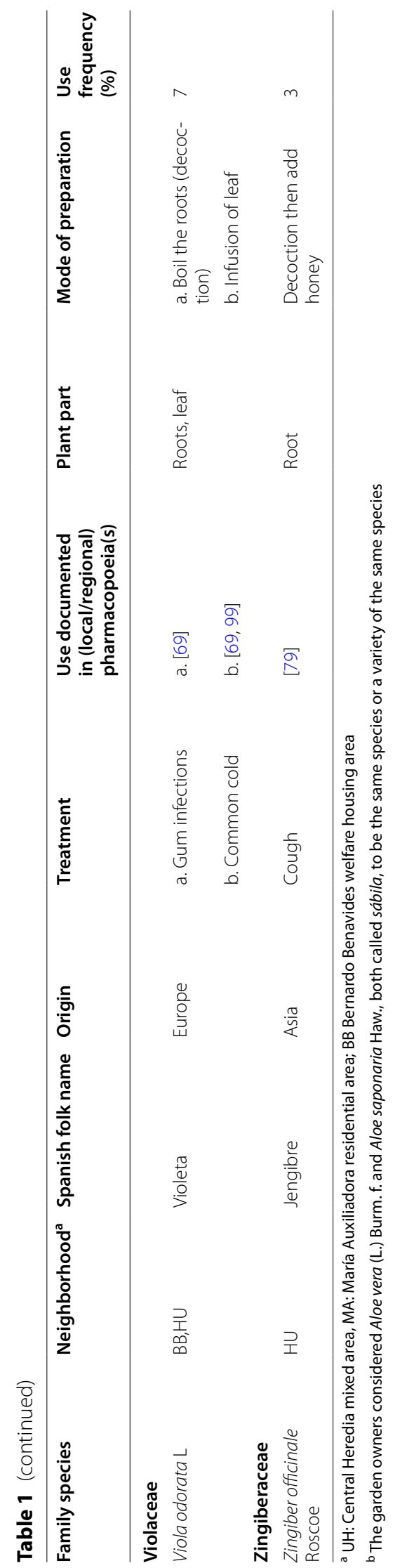


\# gardens

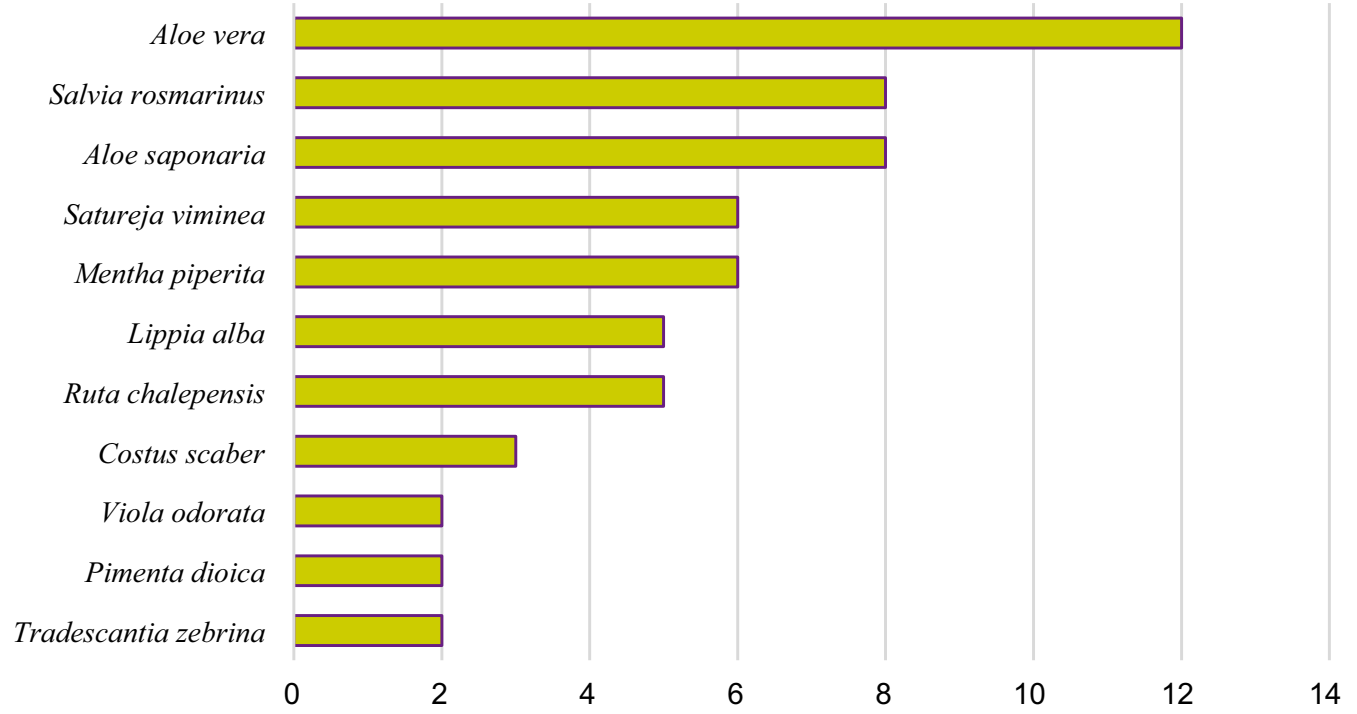

Fig. 2 Species of medicinal plants found in at least two private urban gardens of Heredia

\section{Versatility}

Aloe saponaria, Aloe vera, Costus scaber, Mentha piperita, Salvia rosmarinus, Satureja viminea, Ruta chalepensis, Buddleja americana, Lippia alba and Viola odorata were the most versatile species used for treating multiple illnesses.

\section{New uses}

For the 27 species of plants found in this study, eight participants provided new information about treatments for various illnesses that differ from uses found in the regional and local pharmacopoeias. For the following plant species, there was a previously unreported use: Blechum pyramidatum (used after radiation therapy for prostate problems), Aloe saponaria (to treat lipoma, a non-cancerous tumor that is made up of fat cells also called fatty lump and also for earache), Impatiens walleriana (for healing wounds on the hands), Tradescantia zebrina (high blood pressure), Costus scaber (cough and diabetes), Solenostemon scutellarioides (haemostatic), Psidium friedrichsthalianum (cough) and Lippia alba (fractures).

\section{Discussion}

\section{Diversity of medicinal plant species: garden owners' characteristics}

The majority of the garden owners that participated in this study is female. As Howard (2006) has shown in her exemplary research on gender and social dynamics in swidden and home gardens in Latin-America, it is not rare that more women are responsible for home gardens than men. Palheta and colleagues [27] also found that female family members are primarily responsible for taking care of urban home gardens in the Amazonian region of Brazil. Likewise, Duque [102] also found that much of the traditional medicinal knowledge in Colombian urban gardens is shared informally among women, but is also gathered by women who specialize in medicinal plants. In Latin-America, women are considered the keepers of traditional communal social relationships, food security and home health, and as such their participation in garden maintenance is key [8]. Moreover, zooming in on the participants' age, $83 \%$ of them was 50 years or older. This is in line with other urban ethnobotanical research that has shown that experience and knowledge of plants, especially medicinal ones, increases with age [103].

Compared to the total amount of plant species found in the overarching research project [58], the number of medicinal plant species is relatively low. Although other studies from urban areas in Mexico [32], for example, have shown comparable low proportions of medicinal species, compared to rural and suburban areas where the knowledge and use of medicinal plants is typically higher. The presence and composition of medicinal plant species in the studied gardens can be related to diverse factors, such as the personal preferences of the garden owners [104]. According to [32], garden owners managed these places based on tradition, needs and preferences, which means that they include species in their garden for diverse uses. The selection of the plant composition of a garden thus not only depends on the preferences of the garden owner but also on the alimentary, aesthetic and medicinal needs of the garden owners. Moreover, socioeconomic and cultural 


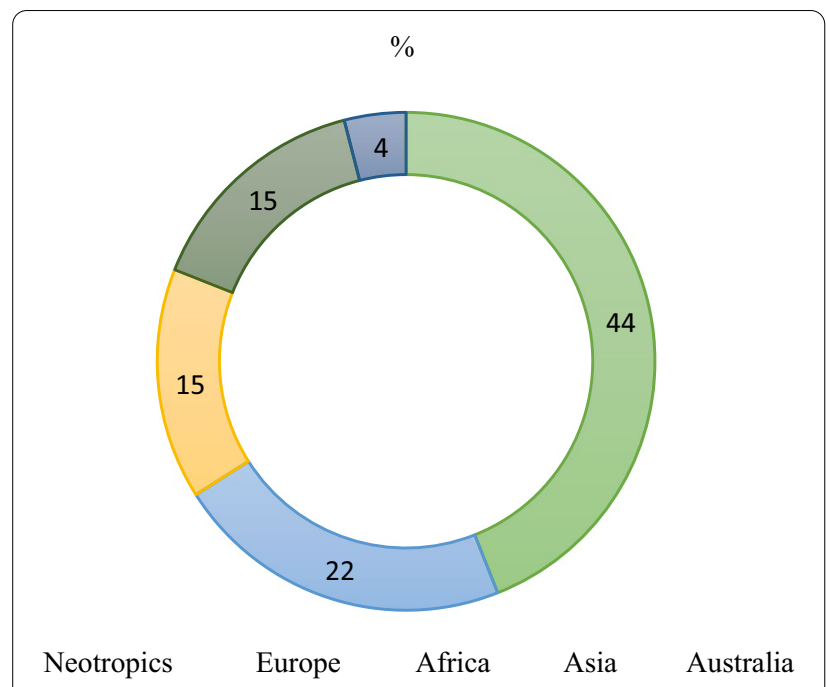

Fig. 3 Natural geographical distribution of the medicinal plants found in the private urban domestic gardens in Heredia, Costa Rica

factors, as well as age and family situation also play a crucial role [104]. Which species garden owners cultivate and use is thus based on highly individualized and experiential knowledge as well as on their socioeconomic situation. As described above, scarce studies about the relation between specific medicinal plants cultivated by urban garden owners and their socioeconomic background seem to point to a socioeconomic gradient, also illustrated by our findings.

We assume that the relatively low number of medicinal plants found in the three areas might also be in part attributed to a low need, given the accessibility of medical care and hospitals located in their neighborhoods. The Costa Rican National Health Service created in 1941 provides reliable and almost universal access to health care [34] with little financial repercussions. Although the complementary use of medicinal plants in Costa Rica has been documented in other urban areas. People interviewed by [49] in a clinic in San José reported using medicinal plants in conjunction with prescribed or over-the-counter medicines without having any information about possible interactions.

\section{Origins of plants species: traces of Costa Rica's colonial history}

Finding exotic medicinal plants in these home gardens was not surprising, as many of these species were introduced during the Colonial Era. The Spanish Conquest of Costa Rica dates back to the sixteenth century. Soon people who were deported as slaves to the Caribbean coast from different African countries ${ }^{1}$

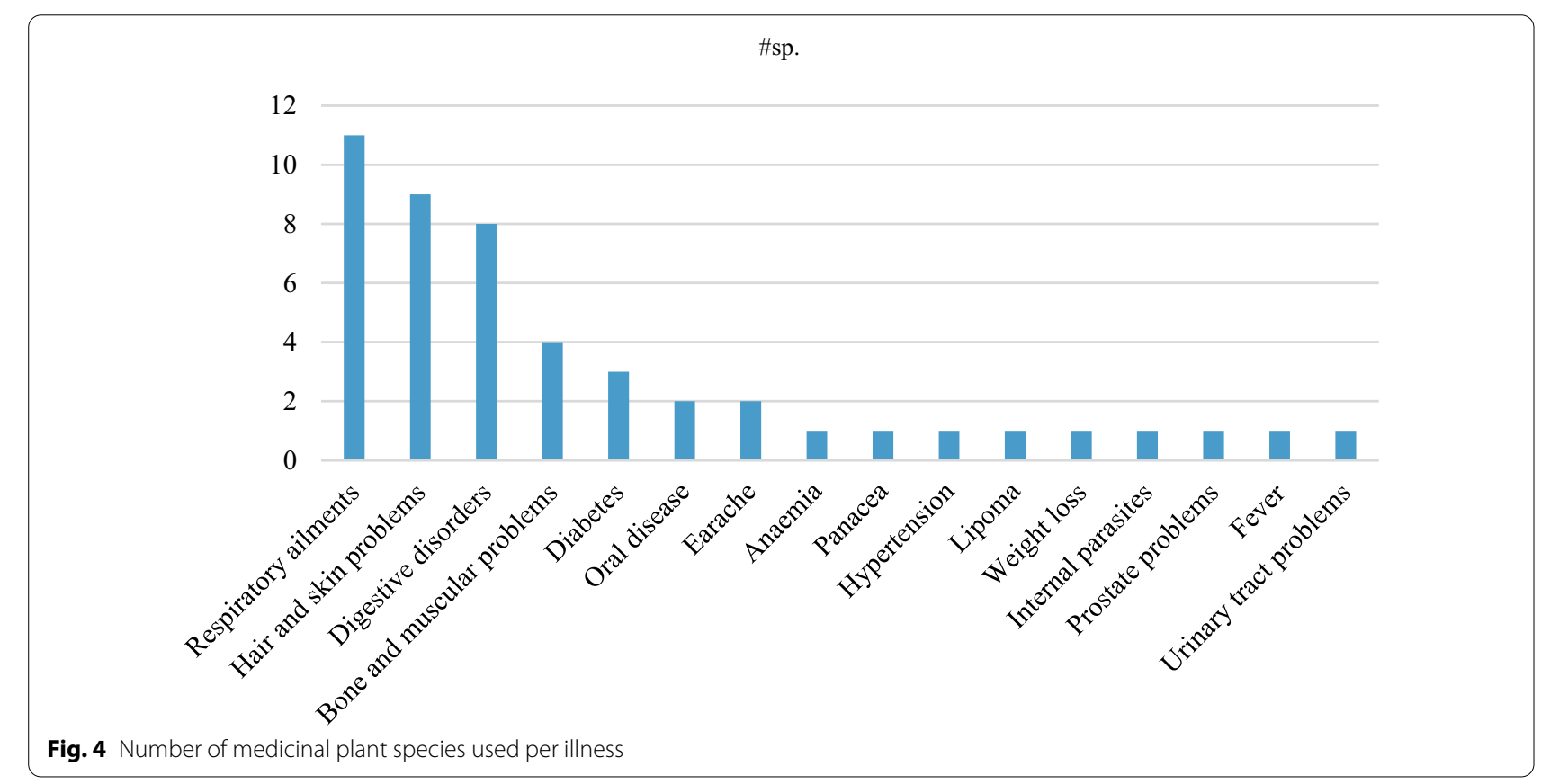

1 The first historic registration of African slaves in Costa Rica dates back to the year 1522-1523 when 30 African individuals were brought by Gil González during his first excursion to the Pacific coast of Costa Rica and Nicaragua, followed by nine others that came with Hernán Sánchez de Badajoz in 1540. By 1569 Monsignor Thiel reported in the population census of Costa Rica a total of 17,479 individuals, of which 30 were described as 'black' people and 170 were described as 'Mulatto,' 'Zambos' and 'Pardos.' 
$[105,106]$ brought with them their own ethnobotanical practices and traditions. In addition to the mentioned Afro-Costa Rican descendants [37], there are several indigenous communities or territorios indigenas (Ngöbe, Bribri, Cabecar, Brunka, Maleku, Huetar and Chorotega) as well as people of European descent, which form a rich cultural mixture [107]. As a result, the current knowledge of medicinal plants in Costa Rica is a rich and hybrid mixture of knowledge from these different ethnic groups. These regional historical processes and cultural diversity are reflected in the medicinal plant uses in this study as well.

For example, Aloe vera, the species that is most frequently used by the participants in this study, was introduced to the Americas from the Canary Islands very early on during the Conquest. The species is now naturalized and found in numerous countries from Barbados, Jamaica, Antigua, Puerto Rico, Mexico to Central America, and as far as Texas, Florida and the Peruvian Andes [108]. Aloe vera is among the most used medicinal plant species reported by the participants and also belongs to most cultivated and consumed plants found in different Latin-American cities [7, 48]. In Costa Rica, there are between 60 and 80 hectares of Aloe vera used mostly as nutritional supplements [109].

Another frequently used species in this study, Salvia rosmarinus or rosemary, was among the first plants brought by the Spaniards during colonial times in Costa Rica in the sixteenth century [110] and still is frequently used today as confirmed in a survey carried out in an urban clinic in San José, Costa Rica [49].

In fact, it has been estimated that about a fourth of all plants used in traditional healing practices and domestic remedies in Costa Rica have been introduced by European colonizers [48], such as ginger Zingiber officinale, cloves Pimenta racemosa, Jamaican pepper Pimenta dioica, cinnamon Cinnamomum zeylanicum and aniseed Pimpinella anisum [111]. About half of the medicinal species grown in home gardens in San José, Costa Rica, are native to the American continent [112].

Similar results were found in other studies throughout the Neotropics. It is assumed that more than half of the herbs once utilized by Spanish colonizers were still cultivated and used all over Latin-America by the mid-twentieth century [113]. More recently, Bennett and Prance have estimated that nearly $80 \%$ of the introduced medicinal plant species that indigenous and mestizos of northern South America used are of European, Mediterranean or Asian origin [114]. These plants were initially introduced as ornamentals and food and were later used for medicinal purposes as well. Exotic medicinal plants have locally well-defined functions which suggests that they have a role in fulfilling specific local necessities that are not satisfied by native species [115]. Furthermore, the higher presence of exotic species of plants in urban gardens is related to the biotic homogenization process, where urbanization decreases the diversity and abundance of indigenous species in urban home gardens in Africa [116].

\section{Versatility and the hypothesis of diversification}

The presence of many introduced medicinal species can be further explained by the versatility and diversification hypothesis that states that exotic plants are more likely to be introduced in traditional pharmacopoeias when fulfilling different purposes simultaneously [117]. Indeed most of the versatile species mentioned by the home garden owners to treat several illnesses are introduced (i.e., Aloe saponaria, Aloe vera, Mentha piperita, Rosmarinus officinalis, Satureja viminea, Ruta chalepensis, Viola odorata) with the exception of Costus scaber, Lippia alba and Buddleja Americana, which are native species. For the latter, no records were found in the pharmacopeia for its use as a panacea, only one participant expressed that it was used for any kind of illness. The observed versatility can be explained by the hypothesis of diversification, which suggests that exotic plants bring diversity to native species of medicinal plants already used, resulting in treatments that have a wider assortment of therapeutic goals and, in some cases, can treat illnesses that native flora cannot, thus providing an evolutionary benefit to the communities that incorporate them in the local pharmacopoeia $[118,119]$. The versatility of introduced medicinal plants, in terms of the numerous conditions treated, may be the result of direct selection by healers or communities for more versatile plants that increase the opportunities for experimentation and, therefore, the probability of discovery of additional medicinal applications [117]. For example, the finding that the Lamiaceae are one of the families with most species in this research, might be related to the fact that many species in this family are used as both medicine and condiments and the importance of this family is mainly due to its species' richness in essential oils that have widely known and studied medicinal properties [120]. This plant family also has the most species of exotic medicinal plants used by indigenous people of the northern part of South America [114].

\section{New uses for lifestyle diseases: a reflection of Costa Rica's epidemiological profile}

For the 27 medicinal species of plants found in this study, eight participants provided new information about treatments for various illnesses that differ from uses found in the regional and local pharmacopoeias [64-70, 72, 74, 107, 121]. Although some of these uses concern treatments for common minor ailments such as digestive problems and cough, 
other treatments involve uses for lifestyle diseases (hypertension, diabetes) and severe conditions (cancer, tumors). These latter types of uses might not be part of the shared common pharmacopoeia yet. Of the 4.301 .712 million people in Costa Rica, $72.8 \%$ live in urban areas and $27.2 \%$ in rural regions [50] and although it is officially a developing nation it has an epidemiologic profile like most developed countries [34]. Costa Ricans have the second-highest life expectancy in the Americas, higher than the USA, Chile and Brazil [122]. According to the census of 2017, the main reason of mortality is related to cardiovascular diseases; secondly cancer and thirdly pneumonia and chronic lung diseases. Moreover, the three principal cardiovascular risk factors (survey 2014) are high blood pressure (suffered by $31.2 \%$ of the population), diabetes $(14,9 \%)$ and overweight and obesity (increasing from 62 to $77.3 \%$ in different age groups) [123-125]. This is in part attributable to a westernized lifestyle with a high intake of saturated fat and physical inactivity. These newly reported uses thus show how knowledge on medicinal plant species even in urban areas is resilient and creatively reapplied onto newly emerging lifestyle diseases. Hence, urban areas can be arenas where new medicinal knowledge is dynamically created, shared and reproduced. This also illustrates the need for more ethnobotanical studies in urban areas in order to preserve the traditional medicinal knowledge of people living in urban areas.

\section{A note on potential adverse uses}

Finally, a concerning finding is that some participants did not specify the dosage they use (see also Table 1), although it is necessary to know the active ingredients of medicinal plants and the variety of their active ingredients in terms of their location in the plant (leaf, seed, stem, root) and their seasonal availability, in order to understand the benefits and risks of using them [100]. In addition, some adverse uses were found. According to Rodriguez ${ }^{2}$ (pers. comm., 2012) Satureja viminea should not be used for medicinal purposes because of this species can affect the liver and kidneys. For verification, more toxicity tests should be conducted since pulegone, a major essential oil component, has been noted to have hepatotoxic function [126]. Another finding that contrasts with existing literature concerns Nopalea cochenillifera which is used for constipation by participants in this study, although its medicinal use has been contested [127].

\section{Conclusions}

There is little information about medicinal plants from urban areas in Costa Rica and especially about plants cultivated by urban private garden owners. This research

\footnotetext{
${ }^{2}$ Hernán Rodríguez is a Costa Rican agronomist and ethnobotanist who currently teaches workshops on the use of medicinal plants for the general public and universities. The first author had assisted in some of his courses.
}

provides information about the medicinal plants used in selected urban areas in Heredia, Costa Rica. Some of the medicinal plants found had other uses than those found in the local and regional pharmacopoeias and others had no previously reported use at all. Several plant species are used to treat several different illnesses. Most plants are used to treat minor ailments, such as respiratory problems, digestive disorders, damaged hair and skin problems by the participants located in this urban area. The majority of the plants were introduced and versatile species, which is most likely related to the cultural mix existent in Costa Rica interconnected with the colonial heritage. It has been suggested before that the Costa Rican government should develop projects to rescue popular plants used for medicinal purposes according to ethnomedical traditions [74]. We agree as stated by TRAMIL [128] that the conservation estate of medicinal plants should be approached not only from a biological perspective, but also from a sociocultural perspective and, as such, should result in a better understanding of the dynamics that involve the ethnobotanical uses of these plants. Validating the correlations of the ethnomedicinal uses, bioactive substances, biological and pharmacological effects is of special importance and is a primary task for future research. Efforts are also needed to investigate the physiological and biochemical functions demonstrated by these understudied species, identifying the individual bioactive natural products and illustrating their mechanisms of action. Hence, we recommend that further studies should be conducted in other urban locations within Costa Rica to add to the current local knowledge of what plants are being used for medicinal purposes.

\section{Appendix}

See Figs. 5, 6, 7, 8, 9, and 10.

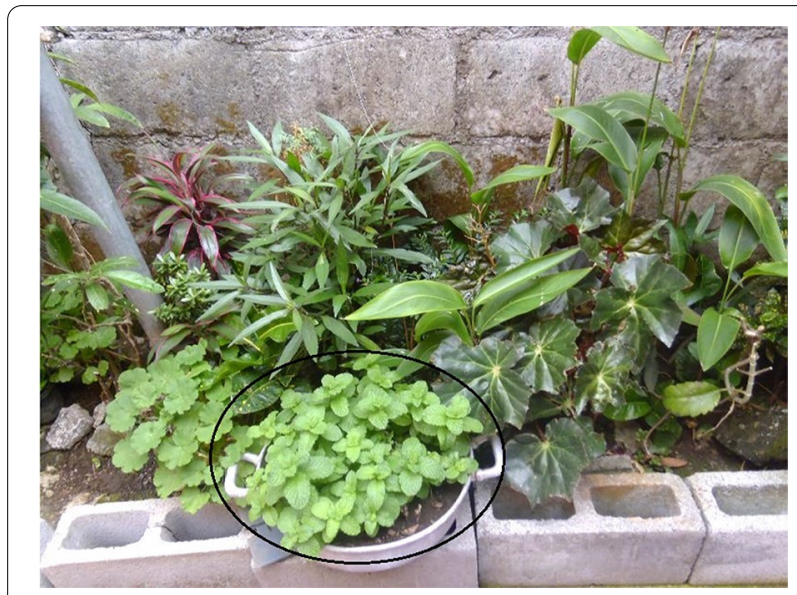

Fig. 5 Mentha piperita $(\mathrm{HU})$ 


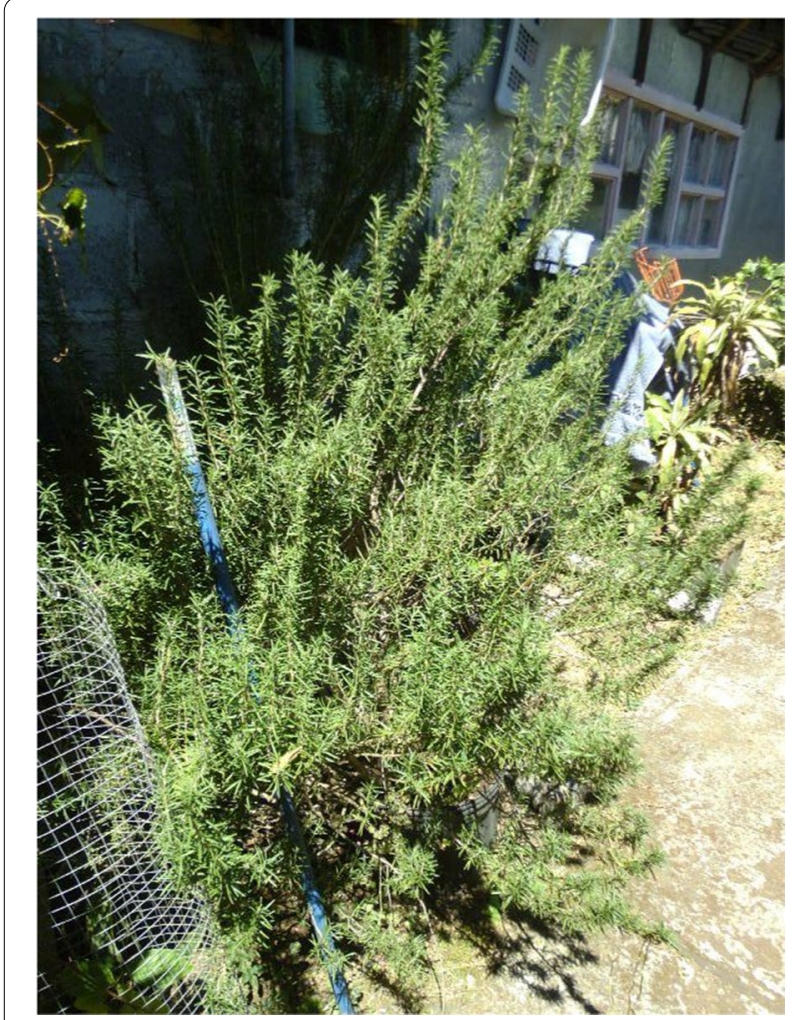

Fig. 6 Rosmarinus officinalis (HU)

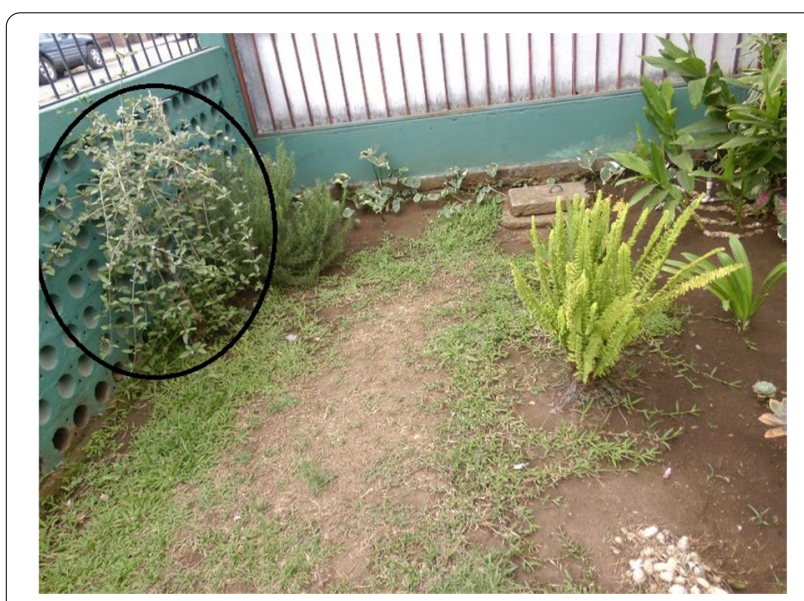

Fig. 7 Lippia alba (HU)

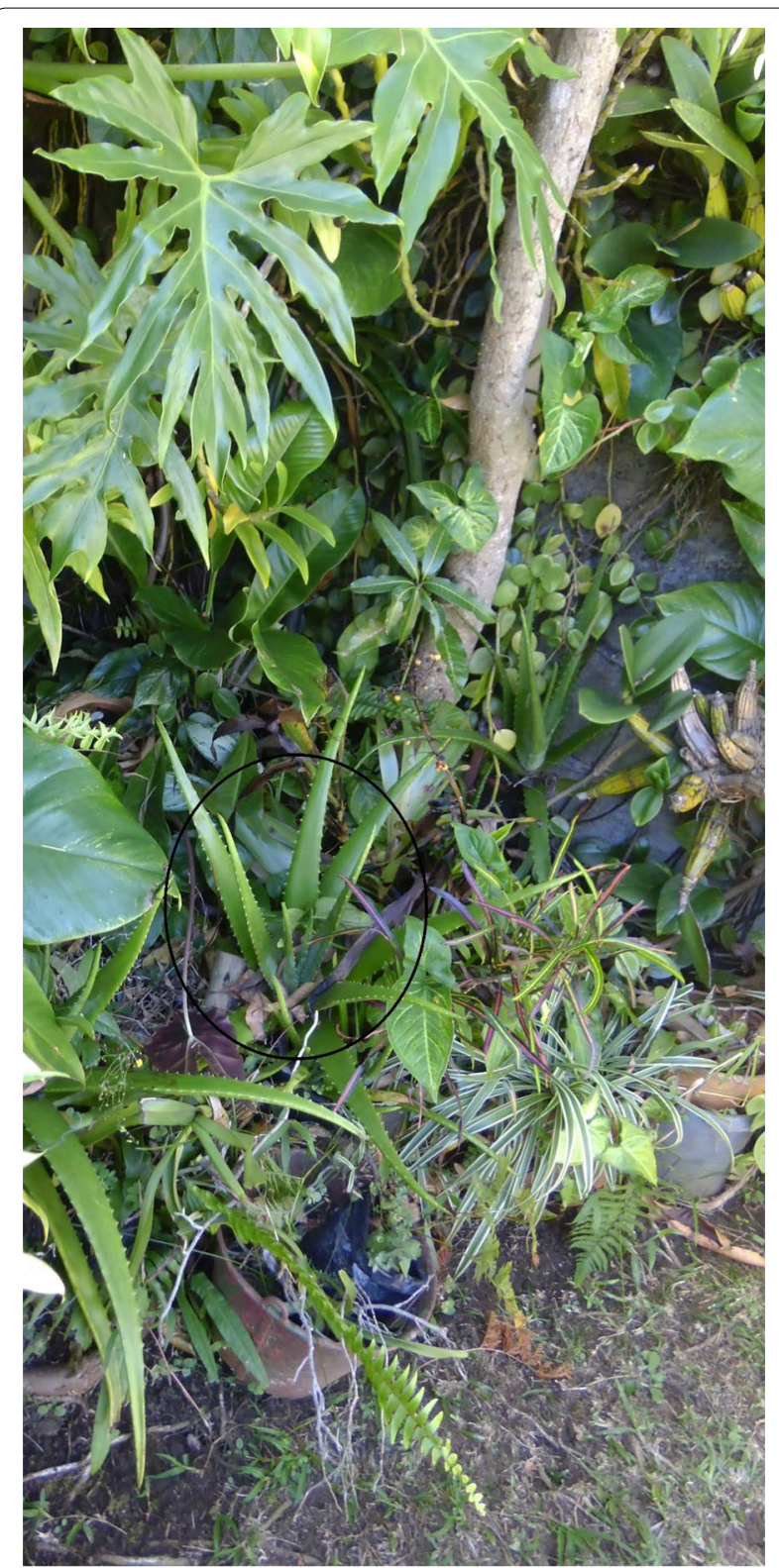

Fig. 8 Aloevera (MA) 


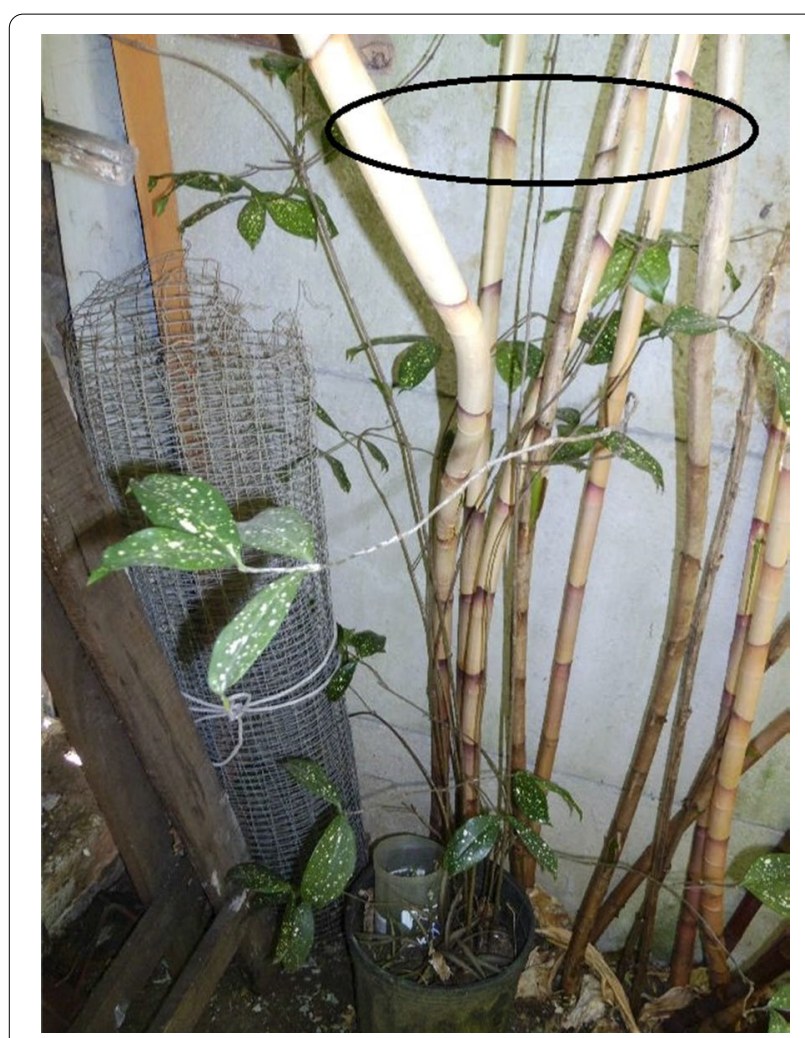

Fig. 9 Costus scaber (MA)

\section{Acknowledgements}

We wish to express thanks to all the garden owners who participated in this research. We appreciate all the help given by Alonso Quesada Hernandez from the National Herbarium, Department of Natural History of the National Museum from Costa Rica. Furthermore, we extend appreciation to Frederick Ball who helped in the editing of this manuscript and to José Pablo Castro Chacón for preparation of the map. Special thanks go to María Sibaja Guerrero, who participated as a field assistant during interviews.

\section{Authors' contributions}

RGB interviews with each garden owner in addition to analyzing the data obtained and searching for literature related to this project. She also wrote the manuscript. TBR and MRV were both committee members and advisors of the thesis where the information of this article was taken from. They helped in selecting the different neighborhoods involved in this research, as well as in correcting the draft and advising during the whole process of this investigation. MC colleborated as an expert advisor. She reviewed and edited the article during all phases and gave specific advice with regard to urban ethnobotany. All authors read and approved the final manuscript.

\section{Funding}

This study received no external funding and was completed as part of a $\mathrm{PhD}$ research.

\section{Availability of data and materials}

Please contact author for data requests.

\section{Declarations}

\section{Ethics approval and consent to participate}

The study obtained a positive advice from the Comisión de trabajos finales de graduación. Acuerdo No.30-2012.

\section{Consent for publication}

Not applicable

\section{Competing interests}

The authors declare that they have no competing interests.

\section{Author details}

${ }^{1}$ Universidad Nacional, Heredia, Costa Rica. ${ }^{2}$ Health and Demographic Research, Ghent University, Ghent, Belgium.

Received: 2 July 2021 Accepted: 20 January 2022

Published online: 12 February 2022

\section{References}

1. Nabhan G. Introduction: letter to young ethnobiologists. Ethnobiology for the future: linking cultural and ecological diversity University of Arizona Press, Tucson, Arizona, USA. 2016:3-9.

2. Barthel S, Folke C, Colding J. Social-ecological memory in urban gardens: retaining the capacity for management of ecosystem services. Glob Environ Chang. 2010;20(2):255-65.

3. Barthel S, Parker J, Ernstson H. Food and green space in cities: a resilience lens on gardens and urban environmental movements. Urban studies. 2015;52(7):1321-38.

4. Finerman R, Sackett R. Using home gardens to decipher health and healing in the Andes. Med Anthropol Q. 2003;17(4):459-82.

5. Emery MR, Hurley PT. Ethnobiology in the city: embracing the urban ecological moment. J Ethnobiol. 2016;36(4):807-19.

6. Applequist WL, Brinckmann JA, Cunningham AB, Hart RE, Heinrich M, Katerere DR, et al. Scientists' warning on climate change and medicinal plants. Planta Med. 2020;86(01):10-8.

7. Furlan V, Kujawska M, Hilgert NI, Pochettino ML. To what extent are medicinal plants shared between country home gardens and urban ones? A case study from Misiones, Argentina. Pharmaceutical Biol. 2016;54(9):1628-40. 
8. Pulido Silva MT. Home gardens as an alternative for sustainability: challenges and perspectives in Latin America. 2008.

9. Macía MJ, García E, Vidaurre PJ. An ethnobotanical survey of medicinal plants commercialized in the markets of La Paz and El Alto. Bolivia J Ethnopharmacol. 2005;97(2):337-50.

10. Bussmann RW, Sharon D, Vandebroek I, Jones A, Revene Z. Health for sale: the medicinal plant markets in Trujillo and Chiclayo, Northern Peru. J Ethnobiol Ethnomed. 2007;3(1):1-9.

11. Bussmann RW, Zambrana NYP, Romero C, Hart RE. Astonishing diversity - the medicinal plant markets of Bogotá. Colombia J Ethnobiol Ethnomed. 2018;14(1):1-47.

12. Bussmann RW, Zambrana NYP, Romero C, Hart RE. No consensus in "traditional" medicine-Medicinal plants and their uses in the markets of Bogotá (Colombia), La Paz/El Alto (Bolivia) and Trujillo/Chiclayo (Perú). 2018

13. de Albuquerque UP, Monteiro JM, Ramos MA, de Amorim ELC. Medicinal and magic plants from a public market in northeastern Brazil. J Ethnopharmacol. 2007;110(1):76-91.

14. Tinitana F, Rios M, Romero-Benavides JC, de la Cruz RM, Pardo-deSantayana M. Medicinal plants sold at traditional markets in southern Ecuador. J Ethnobiol Ethnomed. 2016;12(1):1-18.

15. Ladio AH, Albuquerque UP. The concept of hybridization and its contribution to urban ethnobiology. Ethnobiol Conserv. 2014;3.

16. Hurrell J. Urban Ethnobotany in Argentina: theoretical advances and methodological strategies. Ethnobiology and Conservation. 2014;3.

17. Albuquerque UP, Silva JS, Campos JLA, Sousa RS, Silva TC, Alves RRN. The current status of ethnobiological research in Latin America: gaps and perspectives. J Ethnobiol Ethnomed. 2013;9(1):1-9.

18. H Gonzalez V, Ortiz P, Frausin Bustamante G. Forced migration and indigenous knowledge of displaced Emberá and Uitoto populations in Colombia: an ethnobotanical perspective. Mundo Amazónico. 2012:3:165-77.

19. Tareau M-A, Bonnefond A, Palisse M, Odonne G. Phytotherapies in motion: French Guiana as a case study for cross-cultural ethnobotanical hybridization. J Ethnobiol Ethnomed. 2020;16(1):1-17.

20. Tareau M-A, Greene A, Palisse M, Odonne G. Migrant Pharmacopoeias: An Ethnobotanical Survey of Four Caribbean Communities in Amazonia (French Guiana). Econ Bot. 2021:1-13.

21. Volpato G, Godínez D, Beyra A. Migration and ethnobotanical practices: the case of tifey among Haitian immigrants in Cuba. Hum Ecol. 2009;37(1):43-53.

22. Kujawska M, Pieroni A. Plants used as food and medicine by Polish migrants in Misiones, Argentina. Ecol Food Nutr. 2015;54(3):255-79.

23. Pochettino ML, Hurrell JA, Lema VS. Local botanical knowledge and agrobiodiversity: homegardens at rural and periurban contexts in Argentina. Horticulture. 2012;2012:105-32.

24. Alejandro MAM. Etnobotánica de las plantas medicinales en los huertos familiares de tabasco. Ramón Mariaca Méndez.176.

25. Jacob Paredes D, Buenaño-Allauca MP, Mancera-Rodríguez NJ. Usos de plantas medicinales en la comunidad san jacinto del cantón ventanas, los rí os-ecuador. Rev UDCA Actualidad Divulgación Científica. 2015;18(1):39-50.

26. Solsol HR, Platero GGR Montes IAG. Huertos familiares: Agrobiodiversidad y su aporte en la seguridad alimentaria en territorios rurales de Guatemala. Agroecología. 2014;9:85-8.

27. Palheta IC, Tavares-Martins ACC, Lucas FCA, Jardim MAG. Ethnobotanical study of medicinal plants in urban home gardens in the city of Abaetetuba, Pará state, Brazil. Boletín Latinoamericano y del Caribe de Plantas Medicinales y Aromáticas. 2017;16(3):206-62.

28. Mendoza-García R, Pérez-Vázquez A, García-Albarado JC, García-Pérez E, López-Collado J. Uso y manejo de plantas ornamentales y medicinales en espacios urbanos, suburbanos y rurales. Revista mexicana de ciencias agrícolas. 2011;2(SPE3):525-38.

29. González-García A, Sal AG. Private urban greenspaces or "patios" as a key element in the urban ecology of tropical central America. Hum Ecol. 2008:36(2):291.

30. Luján MC, Martínez GJ. Dinámica del conocimiento etnobotánico en poblaciones urbanas y rurales de Córdoba (Argentina). Boletín Latinoamericano y del Caribe de Plantas Medicinales y Aromáticas. 2017;16(3):278-302
31. Sierra Guerrero MC. Vegetación en los jardines domésticos de la ciudad de Bogotá, Colombia. 2013.

32. Akinnifesi F, Sileshi G, da Costa J, De Moura E, da Silva RF, Ajayi O, et al. Floristic composition and canopy structure of home-gardens in So Lus city, Maranho state, Brazil. J Horticulture Forestry. 2010;2(4):72-86.

33. Caballero-Serrano V, McLaren B, Carrasco JC, Alday JG, Fiallos L, Amigo J, et al. Traditional ecological knowledge and medicinal plant diversity in Ecuadorian Amazon home gardens. Global Ecol Conserv. 2019:17:e00524.

34. Barr EC, Michael M. Leadership, social determinants of health and health equity: the case of Costa Rica. Revista Panamericana de Salud Pública. 2020:44.

35. Helmuth C. Culture and customs of Costa Rica: Greenwood Publishing Group; 2000

36. Tangley L. Costa Rica: test case for the neotropics. Bioscience. 1986;36(5):296-300

37. Ocampo R. Estado de avance en la agroindustria de plantas medicinales en Costa Rica. Agronomía costarricense. 1997;21(1):103-9.

38. Ocampo R, editor Situación del estado de avance en la agroindustria de plantas medicinales en Costa Rica. 10 Congreso Nacional Agronómico y de Recursos Naturales; 3 Congreso Nacional de Fitopatología y 2 Congreso Nacional de Suelos, San José (Costa Rica), 8-12; 1996.

39. Benzecry A. Ethnobotany, anatomy and taxonomy of five tropical lianas of the Coto Brus Region of Costa Rica: City University of New York; 1993.

40. Chazdon RL, Coe FG. Ethnobotany of woody species in second-growth, old-growth, and selectively logged forests of northeastern Costa Rica. Conserv Biol. 1999;13(6):1312-22.

41. Van Zant MK. An ethnobotanical walk with Luis Diego Gómez. Ethnobotanical Leaflets. 2003;1:20.

42. Kappelle M, Juárez ME. Land use, ethnobotany and conservation in Costa Rican montane oak forests. Ecol Conserv Neotropical Montane Oak Forests: Springer; 2006. p. 393-406.

43. Sylvester $\mathrm{O}$, Avalos G, Chávez Fernández N. Notes on the Ethnobotany of Costa Rica's Palms. Palms. 2012;56(4).

44. Hazlett DL. Ethnobotanical observations from Cabecar and Guaymí settlements in Central America. Econ Bot. 1986:40(3):339-52.

45. Koshear J. Guaymí Agriculture, forest utilization and ethnobotany in Coto Brus, Costa Rica: an analysis of sustainability: University of California, Berkeley; 1995.

46. Langlois HC. Ethnobotanical analysis of different successional stages as sources of wild edible plants for the Guaymi people in Costa Rica: University of Florida; 2004

47. Pozo-García SP, Morales CO, García SA. Ethnobotany of the construction of a traditional ceremonial house (Ù-sulế) in a Bribri community of Talamanca. Costa Rica Cuadernos de Investigación UNED. 2020:12(1):137-53.

48. Madaleno IM, editor Traditional medicinal knowledge in Costa Rica. 1 Conference on international agricultural research for development; 2010: University of Bonn Bonn.

49. García González M, Sáenz Campos D, Rojas Mora L, Tinoco Mora Z, Bonilla J. Exploración del uso de plantas medicinales en zona urbana de Costa Rica. Fármacos. 2002:53-64.

50. (INEC) INdEyC. Censo Nacional de Costa Rica. 2011.

51. Salud Md. Memoria Institucional 2010-2014. Presidencia de la República. 2014.

52. Heredia. Md. Información Cantón Central. Recopilado por Marcho Chacón Rojas. 2011.

53. Vargas MR, Castro LP, Chacón RV, Monge RM, Obando FN. Evaluación ecológica rápida de un ecosistema urbano: el caso de la icrocuenca del río pirro, heredia, Costa Rica. Rev Geográfica de Am Central. 2011;2(47):41-69.

54. Roxana G. . Composición florística, uso y manejo de los jardines domésticos urbanos, Heredia. Dissertation. Heredia: Universidad Nacional de Costa Rica; 2014.

55. Lubbe CS, Siebert SJ, Cilliers SS. Political legacy of South Africa affects the plant diversity patterns of urban domestic gardens along a socioeconomic gradient. Sci Res Essays. 2010;5(19):2900-10.

56. Davoren E, Siebert S, Cilliers S, Du Toit MJ. Influence of socioeconomic status on design of Batswana home gardens and associated plant diversity patterns in northern South Africa. Landscape Ecol Eng. 2016;12(1):129-39. 
57. Kuras ER, Warren PS, Zinda JA, Aronson MF, Cilliers S, Goddard MA, et al. Urban socioeconomic inequality and biodiversity often converge, but not always: A global meta-analysis. Landscape and Urban Planning. 2020;198:103799.

58. González-Ball R, Bermúdez-Rojas T, Romero-Vargas M. Floristic composition and richness of urban domestic gardens in three urban socioeconomic stratifications in the city Heredia. Costa Rica Urban Ecosystems. 2017;20(1):51-63.

59. Martin GJ. Ethnobotany: a methods manual: Routledge; 2010.

60. Vogl CR, Vogl-Lukasser B, Puri RK. Tools and methods for data collection in ethnobotanical studies of homegardens. Field Methods. 2004;16(3):285-306

61. Hernández-Sampieri R, Torres CPM. Metodología de la investigación: McGraw-Hill Interamericana México^ eD. F DF; 2018.

62. Reyes-García V, Marti N, McDade T, Tanner S, Vadez V. Concepts and methods in studies measuring individual ethnobotanical knowledge. J Ethnobiol. 2007;27(2):182-203.

63. Ocampo R. El uso de las plantas medicinales en Costa Rica. San José: Litografía e Imprenta LIL, S.A; 1987.

64. Portillo de Rivas RM, Castillo Arévalo S, Orellana de Nieto LE. Obtención y aprovechamiento de extractos vegetales de la flora salvadoreña. Obtención y aprovechamiento de extractos vegetales de la flora salvadoreña1989. p. 480-

65. Gupta MP. 270 Plantas medicinales Iberoamericanas. Programa Iberoamericano de Ciencia y Tecnología para el Desarrollo. Subprograma de Química Fina Farmacéutica Convenio Andrés Bello. : Edición CYTEDSECAB; 1995.

66. House P, Lagos-Witte $S$, Ochoa L, Torres C, Mejía T. Plantas medicinales comunes de Honduras. Tegucigalpa, HN: Universidad Nacional Autónoma; 1995.

67. Cáceres A. Plantas de uso medicinal en Guatemala. Editorial universitaria. Colección Monografías Vol. 1996(1).

68. Sosa Gómez R. El poder medicinal de las plantas. 1997. Report No.: 1575540835.

69. Pamplona R. Enciclopedia de las Plantas Medicinales. Biblioteca Educación y Salud. Safeliz España. 2002:558.

70. Consortium IMPG. Indian Medicinal Plants Growers' Consortium. 2003.

71. UAG G. Farmacopea vegetal caribeña. Farmacopea vegetal caribeña2005. p. 487-.

72. Nuñez Meléndez E. Plantas medicinales de Costa Rica y su folclore. 1978.

73. Quesada Hernández A. Plantas al servicio de la salud: plantas medicinales de Costa Rica y Centroamérica. 2008.

74. Navas HR. La utilidad de las plantas medicinales en Costa Rica: Universidad Nacional Costa Rica; 2000.

75. A. Q. Plantas al servicio de la salud 2: Plantas medicinales de Costa Rica y Centroamérica. : Museo Nacional de Costa Rica; 2010.

76. Ceuterick M, Vandebroek I, Torry B, Pieroni A. Cross-cultural adaptation in urban ethnobotany: the Colombian folk pharmacopoeia in London. J Ethnopharmacol. 2008;120(3):342-59.

77. Bernhardt E. Medicinal Plants of Costa Rica: Zona Tropical; 2008.

78. Pineda AG. Flora útil: etnobotánica de Nicaragua: Gobierno de Nicaragua, MARENA; 2006

79. Earle JS, Sánchez Vindas P. Plantas medicinales en el Trópico Húmedo: San José, CR: Edit. Guayacán; 2001.

80. Salehi B, Albayrak S, Antolak H, Kręgiel D, Pawlikowska E, Sharifi-Rad M, et al. Aloe genus plants: from farm to food applications and phytopharmacotherapy. Int J Mol Sci. 2018;19(9):2843.

81. Bosch C. Medicinal plants; plant resources of tropical Africa. Backhuys Publishers/CTA; 2008.

82. Rayburn D. Let's Get Natural with Herbs: Ozark mountain publishing; 2007.

83. Silva MA, Trevisan G, Klafke JZ, Rossato MF, Walker CIB, Oliveira SM, et al. Antinociceptive and anti-inflammatory effects of Aloe saponaria Haw on thermal injury in rats. J Ethnopharmacol. 2013;146(1):393-401.

84. Ávila LM, DÍAZ M. JA Sondeo del mercado mundial de Sábila. Aloe vera.

85. Nicolas J-P, Descalzos AM. Manual de Plantas medicinales del altiplano de Guatemala para el uso familiar: Asociación Médicos Descalzos; 2013.

86. Ortiz JL. Aloe Vera: La Planta del Futuro: Sabila: AuthorHouse; 2010.

87. Selva FDL. Costus scaber 2013.
88. Mwine J, Van Damme P. Euphorbia tirucalli L.(Euphorbiaceae) The miracle tree: Current status of available knowledge. Scientific Research and Essays. 2011;6(23):4905-14

89. Quispe Valencia D. Uso terapéutico de menta piperita (menta) en pobladores del asentamiento humano Las Lomas de la Pradera. Pimentel. Chiclayo, setiembre 2014-setiembre 2015. 2016.

90. Bonilla DM, Mendoza Y, Moncada CE, Murcia O, Rojas ÁP, Calle J, et al. Efecto del aceite esencial de Rosmarinus officinalis sobre Porphyromonas gingivalis cultivada in vitro. Revista Colombiana de Ciencias Químico-Farmacéuticas. 2016;45(2):275-87.

91. Andrade JM, Faustino C, Garcia C, Ladeiras D, Reis CP, Rijo P. Rosmarinus officinalis L.: an update review of its phytochemistry and biological activity. Future science OA. 2018;4(4):FSO283.

92. De Oliveira JR, Camargo SEA, De Oliveira LD. Rosmarinus officinalis L.(rosemary) as therapeutic and prophylactic agent. Journal of biomedical science. 2019;26(1):1-22

93. Avila-Sosa R, Navarro-Cruz AR, Vera-López O, Dávila-Márquez RM, Melgoza-Palma N, Meza-Pluma R. Romero (Rosmarinus officinalis L.): una revisión de sus usos no culinarios. Ciencia y mar. 2011;15(43):23-36.

94. Zhang L, L Lokeshwar B. Medicinal properties of the Jamaican pepper plant Pimenta dioica and Allspice. Current drug targets. 2012;13(14):1900-6.

95. Duke JA. Duke's handbook of medicinal plants of Latin America: CRC press; 2008.

96. Kirk TK. Tropical Trees of Florida and the Virgin Islands: A guide to identification, characteristics and uses: Pineapple Press Inc; 2009.

97. Rigat M, Bonet MÀ, Garcia S, Garnatje T, Valles J. Studies on pharmaceutical ethnobotany in the high river Ter valley (Pyrenees, Catalonia, Iberian Peninsula). J Ethnopharmacol. 2007;113(2):267-77.

98. Scarpa GF, Rosso CN. Etnobotanica historica de grupos criollos de Argentina IV. Bonplandia. 2019;28(1):5-42.

99. Gloria Garza MA. Evaluación del efecto antimicrobiano de extractos y chalepensina de Ruta chalepensis L.(RUDA) CONTRA Streptococcus mutans, Porphyromonas gingivalis y Cabduda albicans: Universidad Autónoma de Nuevo León; 2016.

100. Singh A, Dhariwal S. Navneet. Traditional uses, Antimicrobial potential, Pharmacological properties and Phytochemistry of Viola odorata: A Mini Review. Journal of Phytopharmacology. 2018;7(1):103-5.

101. Puerta D, León M. Uso de plantas medicinales en la comunidad de Higuerón del estado Yaracuy. Monografía en Internet] INIA Divulga. 2009:13-6.

102. Quesada Hernández A, Lobo CS. Plants useful in the local cultures of El Rodeo, canton of Mora, San José, Costa Rica. Brenesia. 2012;77:147-64.

103. Duque M, Gómez CM, Cabrera JA, Guzmán JD. Important medicinal plants from traditional ecological knowledge: the case La Rosita community of Puerto Colombia (Atlántico, Colombia). BLACPMA. 2018;17(4).

104. Pradeiczuk A, Eichemberg MT, Kissmann C. Urban ethnobotany: a case study in neighborhoods of different ages in Chapecó, Santa Catarina State. Acta Botanica Brasilica. 2017;31:276-85.

105. Eichemberg MT, Amorozo MCdM, Moura LCd. Species composition and plant use in old urban homegardens in Rio Claro, Southeast of Brazil. Acta botanica brasilica. 2009;23:1057-75.

106. Camacho JRQ. Costa Rica contemporánea: raíces del estado de la nación: Editorial Universidad de Costa Rica; 1999.

107. Corrales JR. La esclavitud en Cartago 1750-1775. Diálogos Rev Electrón. 2008;9:787-805.

108. Torres-Avilez W, Méndez-González M, Durán-García R, Boulogne I, Germosén-Robineau L. Medicinal plant knowledge in Caribbean Basin: a comparative study of Afrocaribbean, Amerindian and Mestizo communities. J Ethnobiol Ethnomed. 2015;11(1):1-11.

109. CITES. CITES. Amendments to Appendices I and II of the Convention. Ten-Year-Review proposals. https://cites.org/sites/default/files/eng/ cop/09/prop/E09-Prop-T11_Aloe.PDFundated.

110. Ulate-Molina R, Borbón-Alpízar H, Sibaja-Brenes JP, Vega-Guzmán I, Arguedas-González M. Validación de un método de detección mediante cromatografía líquida (HPLC-DAD) para la determinación de aloína en productos alimenticios elaborados a partir de sábila (Aloe vera). Uniciencia. 2019;33(2):13-26.

111. Co M. Origen, historia natural y usos de las plantas introducidas en Costa Rica. Cuadernos de Investigación UNED. 2020;12:274-399. 
112. Pittier H. Ensayo sobre las plantas usuales de Costa Rica: HL \& JB McQueen, Incorporated; 1908.

113. Álvarez Masís Y. Cocina tradicional costarricense 3: Cartago. San José, Costa Rica: Ministerio de Cultura y Juventud Centro de Investigación y Conservación del Patrimonio Cultural: Imprenta Nacional. 2010

114. Foster GM. Relationships between Spanish and Spanish-American folk medicine. J Am Folklore. 1953;66(261):201-17.

115. Bennett BC, Prance GT. Introduced plants in the indigenous pharmacopoeia of Northern South America. Econ Bot. 2000;54(1):90-102.

116. de Albuquerque UP, de Sousa Araújo TA, Ramos MA, Do Nascimento VT, de Lucena RFP, Monteiro JM, et al. How ethnobotany can aid biodiversity conservation: reflections on investigations in the semi-arid region of NE Brazil. Biodivers Conserv. 2009;18(1):127-50.

117. Mosina GK, Maroyi A, Potgieter MJ. Comparative analysis of plant use in peri-urban domestic gardens of the Limpopo Province, South Africa. J Ethnobiol Ethnomed. 2014;10(1):1-8.

118. Hart G, Gaoue OG, de la Torre L, Navarrete H, Muriel P, Macía MJ, et al. Availability, diversification and versatility explain human selection of introduced plants in Ecuadorian traditional medicine. PloS one. 2017;12(9):e0184369.

119. Alencar NL, de Sousa Araújo TA, de Amorim ELC, de Albuquerque UP. The inclusion and selection of medicinal plants in traditional pharmacopoeias - evidence in support of the diversification hypothesis. Econ Bot. 2010;64(1):68-79.

120. Santos MO, Ribeiro DA, MACÊDO DG, Macedo MJ, Macedo JG, LACERDA MNS, et al. Medicinal Plants: versatility and concordance of use in the caatinga area, Northeastern Brazil. Anais da Academia Brasileira de Ciências. 2018;90:2767-79.

121. Giraldo D, Baquero E, Bermúnez A, Oliveira-Miranda MA. Caracterización del comercio de plantas medicinales en los mercados populares de Caracas. Venezuela Acta Botanica Venezuelica. 2009;32(2):267-301.

122. Vincieri F, Riva A. ESCOP, the European Commission, consumer policy and health protection. Dietary Supplements of Plant Origin: CRC Press; 2003. p. 33-8.

123. Rosero-Bixby L, Dow WH, Rehkopf DH. The Nicoya region of Costa Rica: a high longevity island for elderly males. Vienna yearbook of population research/Vienna Institute of Demography, Austrian Academy of Sciences. 2013;11:109.

124. PROMED. Principales causas de mortalidad en Costa Rica. Cámara Costarricense de Salud; 2020.

125. Roy W. Vigilancia de los factores de riesgo, segunda encuesta. editor. RWM, editor. San José, CR: EDNASSS-CCSS 2016.

126. Hasbum-Fernández B. Epidemiología de la diabetes en Costa Rica. Avances en diabetologia. 2010;26(2):91-4.

127. Suárez A, Echandi MM, Ulate G, Cicció JF. Pharmacological activity of the essential oil of Satureja viminea (Lamiaceae). Rev Biol Trop. 2003;51(1):247-52.

128. Ocampo Sánchez R. Estado de conservación de las plantas medicinales TRAMIL: un aporte a la implementación de la estrategia global para la conservación vegetal: ENDA, San José (Costa Rica) Programa de Investigación Científica de Plantas ...; 2005.

\section{Publisher's Note}

Springer Nature remains neutral with regard to jurisdictional claims in published maps and institutional affiliations. 